\title{
A Comparative Analysis of the Economic Impacts of West Germany and Japan After the Plaza Accord
}

\author{
CHING TAT TSE
}

\author{
${ }^{1}$ UE International Education, Beijing,China, 100089 \\ *Corresponding author.Email:1206659589@qq.com
}

\begin{abstract}
The Plaza Accord has had significant meaning in the last century, no matter economically or historically. This paper analyzes why West Germany experienced more minor impacts due to the Plaza Accord compared with Japan and became one of the strongest economies at that time. The analysis on this problem through data is in terms of many aspects such as monetary, fiscal policies used by two countries, international trade conditions, and some other reasons. From my point of view, the use of expansionary monetary and fiscal policy, an unstable price level that caused money flows into stock and housing markets instead of manufacture industries might be the main reasons why Japan experienced severe economic impacts after this agreement. Also, fiscal and monetary policies used to keep a steady price level, government policies and strict supervision in the housing market, early vocational education, high investment in researches to increase the competitiveness of exported goods and services, and the exchange rate linkage mechanism in the European Community might be the main reasons why German economic recovered and rose rapidly after Plaza Accord compared with Japan economic.
\end{abstract}

Keywords: The Plaza Accord, Economic bubble, Fiscal Policy.

\section{INTRODUCTION}

The Plaza Accord has had significant meaning in the last century, no matter economically or historically. This paper analyzes why West Germany experienced more minor impacts due to the Plaza Accord compared with Japan and became one of the strongest economies at that time. The analysis on this problem through data is in terms of many aspects such as monetary, fiscal policies used by two countries, international trade conditions, and some other reasons. The use of expansionary monetary and fiscal policy, an unstable price level that caused money flows into stock and housing markets instead of manufacture industries might be the main reasons why Japan experienced severe economic impacts after this agreement.Also, fiscal and monetary policies used to keep a steady price level, government policies and strict supervision in the housing market,early vocational education, high investment in researches to increase the competitiveness of exported goods and services, and the exchange rate linkage mechanism in the European Community might be the main reasons why German economic recovered and rose rapidly after Plaza Accord compared with Japan economic.

\section{ANALYSES OF THE DIFFERENT ECONOMIC POLICIES USED BY WEST GERMANY AND JAPAN}

\subsection{A Short Introduction to the Plaza Accord and its Background}

In the 1980s, the United States had deficits in the current account and government budget. The second oil shock increased costs of production and caused a high inflation rate in the United States. To reduce the high inflation rate and stimulate the economy's growth, the US government increased interest rates to attract hot money from abroad. However, the policies increased the current account deficit due to the appreciation of dollars. Meanwhile, Japan, the United Kingdom, West Germany and France were the major trading partners with the United States and the trade deficit with these countries especially Japan increased year by year.Therefore, United States wanted to lower the exchange rate through the Plaza Accord to increase the competitiveness of its exported goods and services. The Plaza Accord included lowering the inflation rate, increasing domestic demand, and increasing intervention in the foreign exchange rate market. After the signing of the Plaza Accord, the Yen 
continued to appreciate against the dollar from 250:1 to 80:1 in a decade. The mark appreciated against the dollar to $1.49: 1$ after 1985 and kept steady for a long time period [1].

\subsection{Analyses of Monetary Policies Used by West Germany and Japan}

\subsubsection{Japan}

Talking about policies, West Germany and Japan used different monetary policies after the signing of the Plaza Accord, and they had different outcomes after that. For Japan, the Japanese government used an expansionary monetary policy because the Yen's appreciation might cause the competitiveness of exported goods and services to decrease. To promote economic growth, the Japanese government wanted to lower the interest rate to increase domestic demand. The deposit interest rate of Japan decreased continually from the year 1985 to the year 1988 by $5.469,3.62,2.75,2.75$ percent respectively, but this change did not bring the expected outcome for the Japanese government. The GDP of Japan was $1.399,2.079,2.533,3.072$ trillion dollars from 1985 to 1990 , and the growth rate of GDP in this period was higher than the growth rate from the year 1980 to 1985, at $1.105,1.219,1.135,1.243,1.318,1.399$ trillion dollars respectively. This is because, initially, the Japanese government thought that the low-interest rate might encourage consumption, and money might flow into manufacture industries to reduce their burden. However, a relatively high inflation rate in Japan caused the cost of borrowing money to decrease, and this encouraged people to invest their money in the stock and housing markets with unstable price levels, so the demand for housing and stocks might increase rapidly, and the GDP of Japan might increase rapidly due to this reason. From the year 1986 to the year 1989, the average price of stocks in Japan rose about 3.68 times [2], and the average price of housing in Tokyo rose about 2.7 times [2], and enormous economic bubbles might have formed in the stock market and housing market. This is because the GDP growth rate was far slower than the growth rate of prices of stocks and housing at that time. The real economy in Japan shrank rapidly, because the earning of manufacture industries was far lower than investing housings and stocks, and money might flow out of the real economy.

\subsubsection{West Germany}

The West German government used expansionary monetary policy at an initial time and contractionary monetary policy at a later time to keep price levels stable. The deposit interest rate in West Germany in the year 1985 was 4.44 percent, and it decreased to 3.2 percent in the year 1987. Later, the German government increased its deposit interest rate to 3.29 and 5.5 percent in the years
1988 and 1989, respectively [3]. The adjustment of deposit interest rates in West Germany was not significant and frequent compared with Japan, so this ensured the price level in West Germany was more stable than in Japan. A stable price level in West Germany might not cause hot money to flow into the stock market and the housing market from manufacture industries and local people. This is because a steady price level might not encourage speculators to invest in stocks or housing. According to [4], the share index in West Germany increased by about $75.31 \%$, and the growth rate in the price of housing was below $10 \%$ from the year 1985 to the year 1990 and from the year 1983 to the year 1990, respectively. Hence, manufacture industries in West Germany had enough money to promote industry upgrading and invest in technology innovation, so local manufacture industries might be able to lower production costs and become more competitive in the international market compared with Japanese industries in later time.

\subsection{Analyses of Fiscal Policies Used by Japan and West Germany}

\subsubsection{Japan}

According to Quan's and Xia's paper, different fiscal policies were used by Japan and West Germany. For Japan, the Japanese government used expansionary fiscal policies from the year 1986 to the year 1988 because the appreciation of the Yen might cause deflation. In 1987, the Japanese government increased government spending by about six hundred trillion dollars [3] to stimulate domestic demand and economic growth. Meanwhile, Japan started to set taxation on land to prevent hot money flowing into the housing market and increased the deposit interest rate from 1988 to 1990 by about $2.75,3.078,5.562$ percent, respectively. This is because the Japanese government might want to let hot money flow into manufacture industries instead of housing and the stock market. However, the combination of the above policies might be the main reason for the bursting of the economic bubble in the housing and stock markets. In this way, most Japanese people who put almost all of their money into purchasing housing and stocks might get almost nothing after the bursting of the housing and stockmarket bubble. Also, many Japanese corporations might be bankrupt or they had to sell their foreign asset due to lack of the cash flow. According to some statistical results, about 3.5 trillion Japanese foreign assets were lost due to the Plaza Accord [5]. Japan started to experience an Lshaped economic recession with an economic growth rate below $1.5 \%$ after the economic bubble burst [5].

\subsubsection{West Germany}

For West Germany, the German government still set a stable price level as the top priority aim, so they used contractionary fiscal policies such as reductions in social 
welfare and subsidies to decrease aggregate demand and government intervention in the market. These policies helped the German government keep a low inflation rate and control the flow of hot money, and ensured German manufacture industries received enough investment for industry upgrading and technology innovation to increase their market share in the international market.

\section{JAPANESE AND WEST GERMAN INTERNATIONAL TRADE CONDITIONS}

\subsection{Japan}

West Germany and Japan had different international trade conditions before the Plaza Accord.

Japan was the biggest trading partner of the United States at that time. In the year $1980,24.2 \%$ of Japanese exported goods and services were sold to the United States. Before the signing of the Plaza Accord, Japanese industries had large market shares in the United States in many areas, such as the semiconductor, car, steel, and shipbuilding industries. The sign of the Plaza Accord is mainly because, since the 1970s, the trade deficit between Japan and the United States accounted for $30 \%$ of the overall United States deficit and had significant impacts on Japanese export industries. The Yen's appreciation led to the reduction of the overall export value of Japan, about 40.072,33.9222, 32.3852 billion dollars a year in 1985,1986 and 1987 respectively [6].

\subsection{West Germany}

For West Germany, West German exports to the United States accounted for a far smaller proportion of overall exports compared with Japan, and West Germany was in the European Community at that time. In 1972, the European Community established the exchange rate linkage mechanism, and the fluctuation range of the currencies of the countries in the region was limited to $2.25 \%$ [1]. In this way, an immense appreciation of marks might not have an enormous economic impact on West Germany. This is because the major trading partners of West Germany were the member states of the European Community, and the exchange rate between West Germany and these countries was steady. In other words, although the export value of West Germany to the United States might decrease, the overall export value of Germany might not be affected by the Plaza Accord. The main difference between Japan and West Germany was the major trading partners. West Germany might be able to spread its risks through the exchange rate linkage mechanism of the European Community, but Japan might only face an isolated condition.

\section{ANALYSIS OF THE REASONS FOR THE RAPID ECONOMIC DEVELOPMENT OF WEST GERMANY COMPARED TO JAPAN AFTER THE PLAZA ACCORD}

After analyzing the policies and conditions of Japan and West Germany after The Plaza Accord, it can be found that there are important reasons for West Germany's rapid economic recovery, which are analyzed in the following three aspects: housing policy, vocational education and research investment.

\subsection{Housing Policies}

According to [4], the price level of housing in West Germany was more stable than in Japan. This is mainly because of West German government policies and strict supervision of the housing market [4]. Talking about government policies in the housing market, the Housing Allowance Act, introduced by the German government in 1965 , ensured the supply of housing for people with low income through government subsidies. Also, before 1980, the government spending on social housing was around 115 billion marks. About 6000 thousand social housing units were built in different ways [6]. A large subsidy on buying housing and a sufficient supply of housing ensured speculators might be unable to earn extra profit through trading housing. As far as the strict supervision in the housing market was concerned, a combination of housing taxes at different stages increased the cost of speculating housing. Also, the prices of the housing were accessed by organizations and provided recommended prices before selling in the market. The market prices must be around the prices provided by the organizations [4]. People who charged higher prices than recommended prices of about $20 \%$ or higher would violate economic criminal law and be punished by the German government. The above policies ensured price levels in housing were low and stable, so excess hot money was more likely to flow into manufacture industries.

\subsection{Vocational Education}

German vocational education might also play an essential role in the development of the economy. The education system in West Germany continually provided high-quality workers at low cost to society due to the modern apprenticeship system [7]. The most significant characteristic of this system was that people were trained in vocational schools and enterprises, and the cooperation of vocational schools and enterprises reinforced people's practical skills. Besides, the fees for vocational education are provided by private enterprises, vocational schools, and the government in each state [7], so vocational education might become popular quickly in West Germany due to low costs. In 1985, an investigation indicated that about $67 \%$ of laborers accepted vocational education in Germany[7].Massive and high-quality 
laborers who are familiar with a large amount of advanced technology might be helpful for manufacture industries to upgrade to increase the competitiveness of their exported goods and services.

\subsection{Investment in Researches}

Besides, a continuous increase in investment in researches might be another advantage compared with Japan. The growth rate of investment in research in West Germany was $15 \%$, which was the highest percentage in Europe [3] in the 1960s. In the 1980s, the investment in research was still proliferating, with 52.2 billion marks in the year 1985 and 60 billion marks in the year 1988 [3]. The proportion of exporting technology inventions increased from $30 \%$ to $38 \%$ from the year 1986 to the year 1988 [3]. We can see that technology played an indispensable role in West Germany's economic development. The government strongly supported the structural upgrading of exported goods and services through increasing the investment in research. The new technology innovations sold abroad help West German industries earn extra profit, and new equipment used in manufacturing processes significantly increases their productivity and lowers their production costs to increase their competitiveness.

\section{CONCLUSION}

This study analyzes why West Germany experienced smaller impacts on its economy after the Plaza Accord compared with Japan, primarily through data. Through the analysis, we might be able to conclude that economic policies used by West Germany to keep a steady price level, the exchange rate linkage mechanism in the European Community, relatively complete laws and strict supervision in the housing market, early vocational education, and high investment in research might be the main reasons why West Germany recovered and rose rapidly. These differences in economic policies, international relations, laws, and technology between the two countries brought different outcomes after the Plaza Accord. Beyond that, there are still many improvements needed in this study in terms of data collection and methods of analysis. Firstly, more collection of historical data might be needed to get a more accurate result concerning data collection. In other words, insufficient data might lead to an incomplete analysis. Secondly, the monotony of the analysis method leads to a lack of in depth exploration of the problem. These problems need to be improved through continually practicing paper writing skills. In the future, related research can focus on building the connection between the Plaza Accord and the trade war between China and the United States. This is because these two events are pretty similar in many places, and experience of the two events might provide suggestions about the future economic development of many countries.

\section{ACKNOWLEDGMENT}

This study was supported by my parents and teachers, they gave me lots of inspiration about the writing logic of this paper and analysis of the economic impacts related to different factors.

I have benefited enormously from their suggestions. I can say that without their helps, it might be challenge for me to complete this study alone.

\section{REFERENCES}

[1] Li-jun Yang. The Implications of Economic policies of Japan and Germany for China's Economic Reform after plaza Accord [J]. Economic System Reform,2014,(06): 159-163.

[2] Mo Z D. Lessons from the serious imbalance between capital expansion and consumption upgrading in Japan after plaza Accord[J]. Economic Management Digest,2019,(15):69-70.

[3] Yi; Xia Xue-jiao. Policy Comparison and Enlightenment between Japan and Germany in response to "Plaza Accord" [J]. Fujian Forum (Humanities and Social Sciences edition),2012,(09):19-26.

[4] Shi Ziguo comparative analysis of the exchange rate appreciation of Japan and Germany after the plaza Accord -- the appreciation of Yen is not the cause of the Long-term economic downturn of Japan [J]. Financial Theory \& Practice,2014,(07):97-102.

[5] Wang Wenke; Duan Xiao-le. The Significance of plaza Accord on Sino-US Trade Friction [J]. Chinese Market,2021,(17):73-76.

[6] Yu Guoying. Analysis and Enlightenment of Japanese Monetary Policy Operation after plaza Agreement [C]. Zhejiang University,2012.

[7] J: YingLu; CAI Dan. Vocational Education and Postwar Economic Development in West Germany [J]. Journal of Nanning Vocational And Technical College,2004,(02):8-10. 